\title{
Focal Image
}

National Cancer Institute

\section{Source}

National Cancer Institute. Focal Image. NCI Thesaurus. Code C94899.

Any limited region within a subject's image which visually stands out from its surroundings. 